HOW

Volume 29, Number 1, pages 84 - 104

https://doi.org/10.19183/how.29.1.647

THOW

\title{
Promoting Dialogic Action through the Expansion of English Language Learners' Communicative Repertoires
}

\author{
Promoviendo la Acción Dialógica a través de la Expansión de los \\ Repertorios Comunicativos de Aprendices de Inglés
}

\author{
John Steven Gómez-Giraldo ${ }^{1}$ \\ Universidad de Antioquia, Medellin, Colombia
}

\begin{abstract}
This action research study sought to foster dialogic action through the expansion of English language learners' communicative repertoires in a 6th-grade class at a public school in a Colombian town. During the first action research cycle, the restricted concept of communication of the grammarbased syllabus and the competitive and violent interactions between the learners were identified as key issues to address. From a critical perspective of pedagogy and literacy, this study understands that communication in language education should transcend the use of a standard target language, and include multiple linguistic codes and multimodal representative forms. Considering these principles and the issues identified, we designed an action plan for the second action research cycle. This plan consisted of activities that sought to expand English language learners' communicative repertoires and promote reflections on violence and conflict resolution through the analysis and creation of different visual representations. Data were collected through journal entries, semi-structured interviews, and students' artifacts. Findings show how the learners have a diverse and differentiated access to communicative repertoires and how they manipulated available representations to transform meanings. As a conclusion, not enough evidence of the emergence of dialogic action was found since competitiveness and violent

He holds a B. A. in Foreing Language Teaching from Universidad de Antioquia. He is a member of the

"Semillero de Investigación InterAcción". His research interests include interculturality in language education, critical literacies and multimodal communication. Currently, he works as an English teacher at different private institutions. This project was submitted as a requirement of the Bachelor of Education in Teaching Foreign Languages (English-French) at the Escuela de Idiomas, Universidad de Antioquia, in El Carmen de Viboral, Colombia. steven.gomez@udea.edu.co

ORCID ID: https://orcid.org/0000-0001-8325-0352
\end{abstract}

Received: March 31st, 2021. Accepted: October 20th, 2021.

This article is licensed under a Creative Commons Attribution-Non-Commercial-No-Derivatives 4.0 International License. License Deed can be consulted at https://creativecommons.org/licenses/by-nc-nd/4.0. 
interactions in the classroom did not significantly change during the intervention. Nonetheless, embracing the learners' communicative practices created spaces for reflection on complex social and moral topics in the classroom, even if their English linguistic resources were still limited.

Keywords: communicative repertoires, critical pedagogy, dialogic action, multiliteracies, multimodality

\section{Resumen}

Este artículo reporta una investigación acción que procuró promover la acción dialógica a través de la expansión de los repertorios comunicativos en una clase de sexto grado en una escuela pública de un municipio de Colombia. Durante el primer ciclo de la investigación acción, se identificó la mirada limitada de comunicación del plan de estudios y las interacciones competitivas y violentas en la clase como asuntos que se debían abordar. Desde una perspectiva crítica, este estudio entiende que la comunicación trasciende el uso de una lengua objeto estándar e incluye códigos lingüísticos múltiples, así como representaciones multimodales. Siguiendo estos principios y los problemas identificados, se diseñó un plan de acción para el segundo ciclo investigativo. Este plan consistió en actividades que buscaban expandir los repertorios comunicativos de los aprendices y promover reflexiones acerca de la violencia y la resolución de conflictos. La recolección de datos se realizó por medio de diarios de campo, entrevistas semiestructuradas y artefactos de clase. Los resultados muestran cómo los aprendices tienen un acceso diverso y diferenciado a los repertorios comunicativos, y cómo manipularon las representaciones disponibles para transformar sus significados. En conclusión, no se encontró suficiente evidencia de la emergencia de la acción dialógica dado que la competitividad y las interacciones violentas en el aula no cambiaron significativamente. Sin embargo, incluir las prácticas y repertorios comunicativos de los estudiantes creó espacios para la reflexión sobre temas sociales complejos, a pesar de que los recursos lingüísticos del inglés eran aún limitados entre los aprendices.

Palabras clave: literacidades críticas, multimodalidad, repertorios comunicativos, pedagogía crítica, representaciones visuales

\section{Introduction}

From language teaching approaches, such as Communicative Language Teaching (CLT) or Task-Based Language Learning (TBLT), communication in the language classroom consists of developing linguistic skills and interaction through the use of the target language. Despite the great acceptance of these teaching methodologies worldwide, different authors have pointed to the restricted idea of communication that represents this model, taking the native speaker communicative patterns as the norm (Kumaravadivelu, 2016), presenting idealized conversational situations (Kramsch, 2008), and disregarding the complex use of linguistic codes and nonverbal resources in communication (Álvarez, 2016; Castro-Garcés, 2021; Losada \& Suaza, 2018; Quintana, 2020; Rincón \& Clavijo, 2016). In contrast, critical approaches to literacy and post-structuralist perspectives of language have expanded the concept of communication, understanding language and communication not as a set of fixed 
rules and patterns but as social practices localized historically and spatially (Canagarajah, 2017, Ortega, 2019).

These new conceptions have sought to cope with a new communication environment mediated by multimedia and multiculturalism by understanding meaning-making as a complex process in which different linguistic and semiotic resources could be used. From this perspective, the English language class is not only concerned with the use of a standard target language; instead, learners' communicative practices encompass the use of learners' mother tongue and other languages, as well as representative forms such as drawings, visuals, memes, videos, and music.

Knowing of the relevance of new modalities of communication in recent years, especially among young learners, I became interested in observing these practices when conducting my teaching practicum in a 6th grade class at a public urban school in Marinilla. This town is located in the department of Antioquia, Colombia, having about 57,000 inhabitants. Through informal conversations with the students at this school, I concluded that they were engaged in diverse communicative practices to interact online and offline both in English and Spanish. Specifically, they used different kinds of audiovisual modalities such as gaming and TV series. I also noticed that regular class activities and the grammar-centered English language school syllabi were not incorporating these modalities and interests. That is why, when I started planning and teaching English language lessons, I decided to incorporate modalities from the online world with which the students were familiar such as memes, emojis, and chats.

Despite the prominence of these new forms of communication, most language education studies have drawn on a restricted concept of communication which focuses on the development of learners' communicative competence or particular linguistic skills. In Colombia, some studies have focused on methodologies such as project-based learning (Vaca \& Gómez, 2017) or TBLT (Buitrago, 2016; Peña \& Onatra, 2009), authentic materials and activities (Herazo, 2010; Ramírez \& Artunduaga, 2018), and games (Urrutia \& Vega, 2010). Even if these studies report improvements in language learners' communicative competence, they seem to have focused on a particular model of conversational and authentic communication that privileges oral production and functional exchanges in reallife situations, disregarding other communicative practices that could have taken place in the classroom.

In contrast, studies from emergent lines of inquiry in Colombia have drawn on critical and post-structuralist perspectives seeking to understand and incorporate different modalities of language classes at public schools. Specifically, Ortega (2019) documented a teacher's pedagogical experience in which language learners were encouraged to use both English and their mother tongue in the classroom, validating their linguistic and cultural repertoires. 
According to the author, the diversity of linguistic repertoires in the class allowed learners to reflect on their realities and negotiate power relationships in the classroom. Also, in an action research study, Rincón and Clavijo (2016) promoted the creation of multimodal texts such as blogs and videos as a way for learners to inquire about their communities. This experience showed that learners could communicate using different modalities and English while they reflected on community issues. Additionally, a number of studies have been framed within multiliteracy principles to understand connectivity and hypermediality (Quintana, 2020), video-mediated listening activities (Losada \& Suaza, 2018) and learners' meaning-making of their social realities (Castro-Garcés, 2021).

Other studies have concentrated on how critical pedagogy could promote not only the acquisition of linguistic repertoires but also dialogue, collaboration, and reflection in the English language class (Contreras \& Chapetón, 2016; Contreras \& Chapetón, 2017; Echeverri \& Pérez, 2014). For instance, in a collaborative action research project, Ortega (2018) describes the implementation of lessons that addressed bullying and violence at the school. This experience enabled the learners to be conscious of the normalized violence there and collaborate to take concrete actions. These critical-oriented studies show an emergent interest in expanding the view of communication in Colombian language classrooms. Nevertheless, further exploring the new dynamics of meaning-making in language education is necessary as well as incorporating multimodal communication in curricula and teaching materials (Álvarez, 2016).

In addition to the necessity of expanding the modalities of communication in my classes, as I continued teaching, I observed several issues of social interaction among the students. Specifically, class activities tended to be individual and a competitive environment was enhanced. Thus, the learners were constantly comparing their grades when working in groups, low-achiever students were rejected, and conflicts frequently arose among them. In those cases, instead of dialogue, the students resorted to violent physical and verbal interactions. Therefore, to face those problematic interactions, and inspired by the previously mentioned studies, I wondered how drawings, memes, comics, or emojis could enable the students to learn a new language, and to communicate, cooperate, and relate peacefully.

In particular, I decided to design an action plan considering the diversity of the learners' communicative practices and the problematic ways in which they interacted. Specifically, I designed a series of activities that sought to address violence explicitly and promote cooperation and reflection among the learners through the use of modalities of representation such as comics, infographics, collages, or pictures. To implement these activities, I sought to (1) understand and incorporate the learners' communicative practices and repertoires in the English language class, (2) expand their communicative repertoires, (3) generate reflections on violence and conflict resolution, and (4) promote dialogue and cooperation among them. In light of these aims, the action research project followed this research question: How 
can one foster dialogic action through the expansion of language learners' communicative repertoires?

\section{Theoretical Framework}

In this section, I present the theoretical approaches and concepts that illuminate this study. In the first place, I briefly define the traditional concept of communication in language education, outline a number of criticisms of this concept and present a view of communication as a situated social practice. Then, I describe how traditional views could be broadened from a critical and post-structuralist perspective of language and education. Finally, from a critical pedagogy, I introduce the concept of dialogic action which goes beyond communication as a mere linguistic exchange, and understands communication as an opportunity to reflect, deliberate, and transform society.

\section{Limitations of Communication as Competence}

"Communicative" is a label that has become commonplace in language education. From the 1980's, Communicative Language Teaching (CLT) has become a dominant force that has shaped every aspect of language pedagogy (Kumaravadivelu, 2006). It continues to exercise an undeniable force in many contexts, including Colombia, where its principles have been adopted in different linguistic policies (MEN, 2006) through the adoption of the Common European Framework of Reference for Languages (Council of Europe, 2001). Despite the great acceptance of CLT, a number of scholars have pointed to the restricted concept that this model conveys. On the one hand, this theory is framed in a center-based model of communication, taking the native speaker's communicative patterns as the reference (Kumaravadivelu, 2016). On the other hand, there is a tendency to present idealized communication situations that disregard power relationships, and clearly ignore the asymmetries of power between different subjects and cultural groups. As stated by Kramsch (2008):

The prototypical communicative exchange found in foreign language textbooks usually includes two or three interlocutors, who all conduct the interaction in the same standard (target) language, all agree on what the purpose of the exchange is and what constitutes a culturally appropriate topic of conversation, all have equal speaking rights and opportunities. (p. 390)

In other words, since communicative competence is defined as an abstract set of abilities, the assumed neutrality of language leads to a disregard for the topics of the conversation and the contents that are taught through language in CLT. Furthermore, CLT only contemplates nonverbal communication as a complement of verbal communication, taking individual 
languages as separate entities with clear borders with respect to other languages and semiotic modalities.

\section{Towards a Broader Concept of Communication}

In the last two decades, post-structuralist theorizations of language have emerged in the field of critical applied linguistics and have dramatically expanded the concept of communication in various ways. From these conceptions, language is no longer conceived as an abstract competence placed in the speaker's mind, but as a social practice that is localized historically and spatially (Canagarajah, 2017). Many concepts such as multiliteracies (Cope \& Kalantzis, 2009), translingual practices (Canagajarah, 2017) and translanguaging (Pennycook, 2017) have created a new paradigm in which the plurality, multiplicity, and hybridity of language is highlighted (Kubota, 2014). Hence, this new understanding of language and communication has many implications for language education. Specifically, the fluid and decentralized nature of linguistic resources imply that languages are not statically framed in individuals, communities, or territories. On the contrary, grammars and meanings emerge and are negotiated in localized communicative practices (Canagarajah, 2017). Furthermore, the borders between different languages and semiotic modes are questioned and rather understood as intrinsic parts of communicative practices that are articulated in particular situations and moments (Pennycook, 2017).

Another way in which communicative repertoires have been expanded is by understanding communication beyond verbal interaction and including other modalities of representation. In this sense, critical conceptions of literacy have sought to cope with the new communication environment brought about by social realities such as multiculturalism, multilingualism, and the extended use of information and communication technologies (Álvarez, 2016; Quintana, 2020). One of these approaches is multiliteracies that theorizes on how new communication practices draw upon different modes of representation or modalities as presented in Table 1 below.

Table 1. Modalities of Representation and Examples. Adapted from Cope and Kalantzis (2009)

\begin{tabular}{|l|l|}
\hline \multicolumn{1}{|c|}{ Modality } & \multicolumn{1}{c|}{ Examples } \\
\hline Written language & Handwriting, printed, on screen \\
\hline Oral language & Live or recorded speech \\
\hline Visual representation & Still or moving image, sculpture, craft \\
\hline
\end{tabular}




\begin{tabular}{|l|l|}
\hline \multicolumn{1}{|c|}{ Modality } & \multicolumn{1}{c|}{ Examples } \\
\hline Audio representation & Music, ambient sounds, noises \\
\hline Tactile representation & $\begin{array}{l}\text { Touch, smell, taste, physical } \\
\text { contact }\end{array}$ \\
\hline Gestural representation & Movements of the hands and arms, expressions of the face \\
\hline Spatial representation & Interpersonal distance, architecture, landscape \\
\hline
\end{tabular}

To understand how communication and meaning-making occur in any of these semiotic modalities, Cope and Kalantzis (2009) propose the concept of design. From this conceptualization, designs are both a structure and a process of creation. That is to say, in any of the modes described above, there could be (1) available designs as found in representational forms, (2) designs, as the appropriation and use of available designs, and (3) redesigns as the transformation of the world and people through the act of designing.

In conclusion, from this broader perspective of communication, language education should not be restricted to developing linguistic skills and conversational interaction in a standard target language. On the contrary, all the linguistic repertoires and representation modalities that learners bring to the class should be valued and considered. The purpose of language teaching should be to expand those repertoires to different linguistic and representational modalities, allowing the learners to participate in society, and exercise the transformative power of communication.

\section{Dialogic Action: Communication for Transformation}

To understand the transformative power of communication in the context of education I drew on the concept of Dialogic Action proposed by Freire (2018). Apart from an expansion of the concept of communication from a linguistic point of view, consideration of the contents, the roles, and the purposes of communicative practices in language education is necessary. In this sense, avoiding the restriction of the role of communication in language education to the use of linguistic resources is paramount to understand how education in general could be considered as a process of communication. From critical pedagogy, education is conceived as a process of dialogue (Freire, 2018) in which different cultural elements are brought to the conversation between the participants in the educational setting. From this perspective, the ultimate purpose of dialogue is the emancipation of the oppressed (Freire, 2018). In that sense, from critical literacies, language education should go beyond the acquisition of the ability to exchange information through the encoding and decoding of different modalities (Álvarez, 2016; Castro-Garcés, 2021; Losada \& Suaza, 2018; Quintana, 2020; Rincón \& Clavijo, 2016); furthermore, communicative repertoires should 
serve the purpose of critically analyzing the unjust contexts and realities of language learners to transform them.

From a Freirian perspective, dialogic action is defined as a contra hegemonic force that seeks to overcome antidialogical forces, by creating public spaces for participation and deliberated action. Accordingly, for Giroux (2001), schools should constitute democratic public spheres where learners can exercise discussion and participation in order to constantly question the hegemonic assumptions in society. By doing so, dialogic action allows the oppressed to emancipate themselves through trust, cooperation for transformation, union for liberation, organization, and systematic and deliberate action (Freire, 2018). Dialogic action allows overcoming the oppressive forces of antidialogical action that prevent the humanization of peoples, by neglecting their right to use the word to construct their own realities, and dividing oppressed peoples through individualism, manipulation, and cultural invasion (Contreras \& Chapetón, 2016; Contreras \& Chapetón, 2017; Echeverri \& Pérez, 2014).

\section{Method}

This study was framed on the principles of qualitative research since it aimed at understanding a particular phenomenon in its context from the perspectives of participants (Creswell, 2012). Additionally, this project followed an action research design as it intended to be a self-reflective, critical, and systematic process of classroom inquiry about my own practices as a teacher (Burns, 2009). This process followed the action research cycle steps proposed by Mills (2011), namely, (1) identifying an area of focus, (2) collecting data, (3) analyzing and interpreting data, and (4) developing an action plan. This project consisted of two complete cycles that took place during my teaching practicum year. During the first semester, I worked as an assistant teacher and identified a focus for the study, collected and analyzed data, and designed an action plan to address the identified issues. In the second semester, I was in charge of teaching accompanied by a cooperating teacher. In this cycle, I implemented the action plan, collected, interpreted data, and reported research findings.

\section{Participants}

During the first semester, I conducted my practicum with a sixth-grade class of 34 students. In the second semester, I implemented the actions with a different group of 35 sixth-grade learners. In both groups, the students ranged from 11 to 14 years old, most of them belonging to middle and low socio-economic strata. Some of them came from different regions of Colombia as well as there were some Venezuelan migrants. As I was conducting my undergraduate practicum in this context, the English language teacher also participated in the class and the research project by being in the class and providing constant feedback 
to me. A consent form was signed by all the parents of the learners who participated in the interviews, or provided class artifacts as part of the data collection. In this report, their identities have been protected through the use of pseudonyms.

\section{Action Plan}

After having observed and taught the English language class for a semester, I proposed the following actions to be implemented during 10 sessions, one weekly, of 2 hours each. Their main purpose consisted of promoting dialogic action through the expansion of language learners' communicative repertoires. What is more, I decided to address issues of violence explicitly, as there were recurrent situations that I observed at the institution. Additionally, I sought to do so through the creation of visual representations as they were one of the communication modalities with which the students were most familiar. I planned to conduct four do-it-yourself workshops and a collaborative project. In groups, the students were going to work on a project in which they could reflect on violent situations in the media, their neighborhoods, or the school, by both analyzing visual representations and creating a visual design to present a reflection around violent situations in their daily lives (see Table 2 below).

Table 2. Action Plan to Address Issues of Violence Using Visual Modalities

\begin{tabular}{|c|c|c|c|}
\hline \multicolumn{4}{|c|}{ Modeling } \\
\hline Week & Action & Purpose & Materials \\
\hline 1 & $\begin{array}{l}\text { Learners survey each other } \\
\text { about media preferences }\end{array}$ & $\begin{array}{l}\text { Understand learners' } \\
\text { communicative practices }\end{array}$ & Survey model \\
\hline 2 & $\begin{array}{l}\text { Analyzing different formats } \\
\text { of visual representations }\end{array}$ & $\begin{array}{l}\text { Model different } \\
\text { formats learners could } \\
\text { use to represent: } \\
\text { poster, collage, } \\
\text { infographic, and flyer. }\end{array}$ & $\begin{array}{l}\text { A model of each } \\
\text { visual design }\end{array}$ \\
\hline 3 & $\begin{array}{l}\text { Analyzing photographs about } \\
\text { different types of material } \\
\text { and symbolic violence }\end{array}$ & $\begin{array}{l}\text { Learners choose a type } \\
\text { of violence to address } \\
\text { in their project }\end{array}$ & $\begin{array}{l}\text { Eight photographs } \\
\text { depicting material and } \\
\text { symbolic violence }\end{array}$ \\
\hline \multicolumn{4}{|c|}{ Do-it-yourself Workshops } \\
\hline 4 & $\begin{array}{l}\text { Using emojis to show } \\
\text { emotions in the classroom }\end{array}$ & $\begin{array}{l}\text { Talk about feelings } \\
\text { in the class }\end{array}$ & $\begin{array}{l}\text { Cardboard, markers } \\
\text { and paint }\end{array}$ \\
\hline
\end{tabular}




\begin{tabular}{|c|c|c|c|}
\hline Week & Action & Purpose & Materials \\
\hline 5 & $\begin{array}{l}\text { Analyzing a cartoon movie } \\
\text { about superheroes }\end{array}$ & $\begin{array}{l}\text { Analyzing violence } \\
\text { in media }\end{array}$ & $\begin{array}{l}\text { A superhero } \\
\text { short film }\end{array}$ \\
\hline 6 & Analyzing and creating memes & $\begin{array}{l}\text { Recognizing physical } \\
\text { and verbal violence }\end{array}$ & $\begin{array}{l}\text { Collection of memes } \\
\text { depicting violence }\end{array}$ \\
\hline 7 & Creating a bubble dialogue & $\begin{array}{l}\text { Reflecting about bullying } \\
\text { and cyberbullying }\end{array}$ & Paper and markers \\
\hline \multicolumn{4}{|c|}{ Project Work } \\
\hline 8 & $\begin{array}{l}\text { In teams, collecting information } \\
\text { for a visual design about a violent } \\
\text { situation in their context }\end{array}$ & \multirow{2}{*}{$\begin{array}{l}\text { Create visual } \\
\text { representations }\end{array}$} & \multirow{2}{*}{$\begin{array}{l}\text { Cameras, } \\
\text { smartphones, } \\
\text { internet connection }\end{array}$} \\
\hline 9 & Learners create their visual design & & \\
\hline 10 & $\begin{array}{l}\text { Final presentation in an } \\
\text { institutional public space }\end{array}$ & $\begin{array}{l}\text { Share learners' } \\
\text { reflections with the } \\
\text { school community }\end{array}$ & $\begin{array}{l}\text { Visual representations } \\
\text { created by learners }\end{array}$ \\
\hline
\end{tabular}

\section{Implementation of Actions}

During the first weeks of this intervention, I had to adapt my action plan in order to fulfill the requirements of the official grammar-centered syllabus of the school. After the 5 th week of the intervention, a sanitary emergency was declared in Colombia as a consequence of the outbreak of the Covid-19 pandemic. This is why all the students went on a break for a month and the sessions were resumed after being redesigned to be conducted through a distancelearning modality. I redesigned the activities for the students to develop independently. I sent instructions via instant messaging. In several cases, I sent physical copies to the students that did not have access to internet connection at home. The distance modality posed many challenges for the implementation of the actions because several students had no access to internet connection, which made communication with them so difficult. Furthermore, developing collaborative work was hardly possible; thus, I was unable to observe the students' interactions during the final weeks of the intervention.

\section{Data Collection and Analysis}

This study included different sources of data that were collected throughout the process from the different student participants and the institution. I kept a journal of each of the sessions (36 entries) in which I took notes about the students' interactions during the session, 
their use of language, and the different forms of communication during the development of the activities. Additionally, I conducted eight semi-structured interviews with a number of the students; I purposefully selected them because their use of communicative resources was illustrative regarding theoretical categories such as mode of communication, design, and dialogue (Creswell, 2012). Following the same criteria, I gathered 10 students' artifacts from three different do-it-yourself workshops containing visual representations and texts. Most data collection was carried out at the school, but after the confinement, a number of artifacts were scanned and sent by students via instant messaging, and several interviews were conducted through video conferences or telephone calls.

The process of data analysis was both inductive and deductive since I defined preestablished categories based on theoretical concepts such as multimodality, design, and dialogic action; I also used emergent categories from data as I considered them relevant regarding the research question. For example, excerpts from journal entries and interviews were categorized as violent interactions, media influence in learners' communication, and differential access to communicative resources. For journals, class artifacts, and learners' interviews, I applied Miles and Huberman's (1994) process of coding and categorization of data assisted by a software called QualCoder (Curtain, 2020). I applied the process of coding to journals and learners' interviews after having read them carefully. I also purposefully selected several class artifacts according to theoretical concepts and coded them following the pre-established categories. After coding and categorization, I displayed the emergent codes and categories visually to identify relationships among them.

\section{Findings}

The data analysis described above allowed me to conclude that enabling learners to use different communicative repertoires and express themselves created spaces for the reflection and transformation of meanings about their realities, even if there is not enough evidence of the emergence of dialogic action among them. Hence, in this section, I present the findings that emerged during data analysis: (1) Learners Communicative Repertoires: Diversity and Difference, (2) Playing around with Forms and Transforming Meanings; and (3) Swimming 94 Upstream: Keeping Relationships among Learners Untouched at School.

\section{Learners' Communicative Repertoires: Diversity and Difference}

One of the aims of this study was to understand and incorporate the language learners' communicative practices and repertoires in the class. In this section, I describe how the learners' communicative repertoires and practices are as diverse as their interests and cultural backgrounds and how they have differential access to these resources. 


\section{Diverse Communicative Practices and Repertoires}

From the analysis of collected data, I could identify a great diversity among the learners in terms of age, gender, socioeconomic background, and geographic origin. This diversity was also reflected in a varied list of communicative repertoires and interests. In particular, during the interviews and class activities, the learners showed familiarity with different media forms including social networks, instant messaging, video games, video streaming platforms, music, films, and television. Despite this wide range of communicative practices in the group, individual learners tended to concentrate on particular formats of communication and personal interests. For example, various learners reported being interested in rap music, YouTubers, anime, and gaming. When I asked one of them about his preferred ways of expression, he answered: "I like to sing mentally (...) the music that I like (...) I like heavy metal and rap music and so on"2 (Interview with Santiago 03/09/2019).

Despite this diversity, an element was common to most of them, namely, the visual modality. According to Kress (2003), this predominance of visual representation is explained by the transition from the page to the screen as the dominant site of representation, where the logic of the image dominates semiotic organization of different texts. In this vein, the learners not only reported being acquainted with visual representations, but they also were more engaged during activities involving reading and creating visual representations.

I could also identify the use of different linguistic resources among the learners. During the observations, I noticed that Spanish was used as the language of interaction and instruction, and English was used mainly in rehearsed classroom routines. Nevertheless, outside the classroom, a few learners reported using words from English in their interactions in instant messaging, listening to music, watching videos, and interacting with English speaking people through video games: "I have an Xbox, so I have some friends that speak English, so I speak with them to learn" (Interview with Andrés, 03/09/2019).

From the previous analysis, apparently, the diversity in the learners' communicative repertoires and practices comes not only from the use of English and Spanish in the classroom but also from their use of different tools and media in online and offline environments. As reported by Quintana (2020), the use of technological devices in the class allowed learners to produce multimodal texts by hybridizing the digital and the analogous.

\section{Differential Access to Communicative Repertoires}

The differential access to material resources emerged as one of the factors that could explain the differences in the learners' communicative repertoires. This was particularly

All the excerpts were translated from Spanish for publication purposes. 
evident during the development of the activities on a distance learning modality due to the pandemic. As communication with several learners was limited because of their lack of access to the internet, or technological devices, they needed to work on paper, and in some cases I was unable to receive their work.

In the two interviews I conducted at the end of the implementation, apparently, the differences in the access to material resources such as internet connection or electronic devices had an impact in the communicative repertoires to which the learners had access. One of the learners without an internet connection at home reported using his dictionary to look up words when working at home. When asked about internet connection at home, he replied that he usually rented a computer in a stationary store, as many students in Colombia do: "I don't, [have a computer] so I go to a stationary store to look up for the answer"3 (Interview with Juan 11/05/2020).

On the contrary, another learner manifested having a cellphone, a computer, and internet connection at home. This learner also expressed that when working on the activities: "We do research, or we also have a lot of books, or sometimes the things that mom knows"1 (Interview with Tomás 12/05/2020). He usually looked up vocabulary on an online translator and had studied English and French in his former private school. The use of linguistic repertoires was also reflected in the work of a number of learners, who have had access to English language courses in private settings or at their former public schools in which they were able to transcend simple formulaic sentences (see Figure 2 below) to present more elaborated ideas (see Figure 3 below).

The contrast between these two cases shows how the material access to resources plays a role in the symbolic access to differentiated communicative repertoires. Following Janks (2010), "access to discourse is highly regulated and that system of exclusion produces distinctions which privilege those who get through the discourse gates" (p. 133). In this sense, this author points to the way different discourses, literacies, and linguistic codes are differentiated, in the sense that they have different statuses. At the same time, they are differentiating in the sense that they classify subjects according to the discourses to which they have access.

\section{Playing around with Forms and Transforming Meanings}

The implementation of the action plan sought to embrace and expand learners' communicative repertoires and generate reflections on violence and conflict resolution in the class. In this section, I explore how embracing those practices and resources in the English

In the town of the study, stationary stores or paper supply stores often rent out computers with internet connections to the public on an hourly basis. 
language class created spaces for the learners to manipulate various forms of representation, engage in reflections, and transform meanings.

\section{Using and Breaking Molds}

When manipulating the available designs introduced in the lessons, there were various degrees of transformation both in the linguistic forms and in the visual representations. When I presented linguistic and multimodal designs to the students, they tended to manipulate and transform them in different ways. According to the data, I could identify that these differences could be attributed to some extent to the different attitudes towards the English language and the diverse and differential communicative resources of the learners.

On the one hand, I could observe how various learners' attitudes and beliefs about the English language did not favor their ability to use the language creatively. Since the class and the official syllabus focused on grammar, they tended to think of language as a fixed set of rules, and thus were fearful of committing mistakes. On the other hand, the differential communicative repertoires of the learners could explain how a number of them were attached to the linguistic models presented in class, while others were able to make more significant transformations to those designs by using more complex grammatical structures to express their ideas.

Nonetheless, the fidelity to the available design, or its redesign, was also evident when working with visual representations. In one of the do-it-yourself workshops, I presented the learners with Marvel superheroes and asked them to create their own superheroes. Different learners created their own versions of Marvel superheroes; others created superheroes that consistently kept their mainstream characteristics; commonly, the learners created more human and close versions of superheroes. When asked about the process of creation, one learner replied that he "was inspired by his pet and also by Dragon Ball, or other movies that I have watched with my cousin, for example Batman, Superman, or movies that we have like the Justice League"1 (Interview with Tomás 12/05/2020). As explained by Dovchin, Pennycook, and Sultana (2018), the engagement with different forms of popular culture not only provides content to the conversations but also voices and linguistic resources. In this line, Losada and Suaza (2018) also point to the role the media play in learners' understanding of different cultures and contexts.

With their limited English linguistic resources, some of the learners were prevented from expressing complex ideas; however, in some cases, they were able to use visual representations or Spanish to do so. For instance, after reading a comic about bullying in English, one of the learners wrote the following reflection in Spanish: "The reflection could be that sometimes problems could be solved with a smile and talking, we cannot discriminate [against] other people, and maybe give a hand to those who need it can help us find a new 
friend"1 (Class artifact 18/05/2020). This is consistent with the experience of Janks (2010) in a primary school third level class in a multilingual context in South Africa, where she found that the limited linguistic ability of children "limits what can be said" (p. 131), and that they could convey more meaning by using visual representations.

\section{Transforming Meanings}

The analysis of different class artifacts allowed me to confirm that the redesign of available visual and linguistic representations served the purpose of transforming the meanings conveyed in those representations. In several cases, the available designs that were presented in class were transformed in order to express facts about the learners' realities. For example, one learner created a more human superhero that could help save lives during the Covid-19 pandemic (see Figure 1 below).

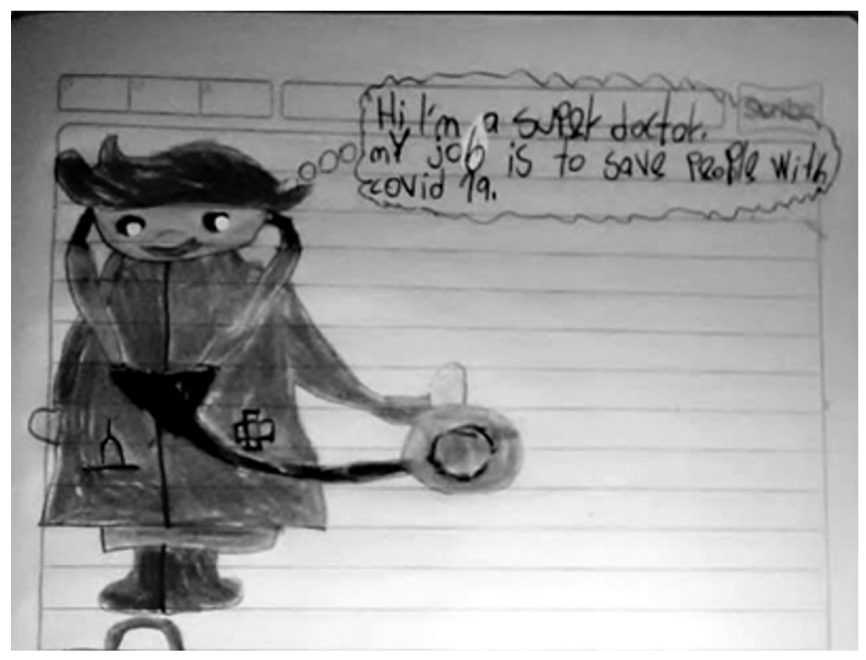

Figure 1. A Learner Presents a Medical Doctor as a Superhero Note. "Hi, I'm super doctor, my job is to save people with covid 19" (Class artifact 19/05/2020)

Sharing these visual representations with the class was an interesting exercise as other learners started creating new transformations to this design. A few learners made modifications in order to create something they could identify with. Others reported having imagined themselves as superheroes in the process of creation of their superhero. One of them created a version of a doctor with whom she could identify and named her "doctora" in Spanish, which allowed her to make her gender explicit (see Figure 2 below). 


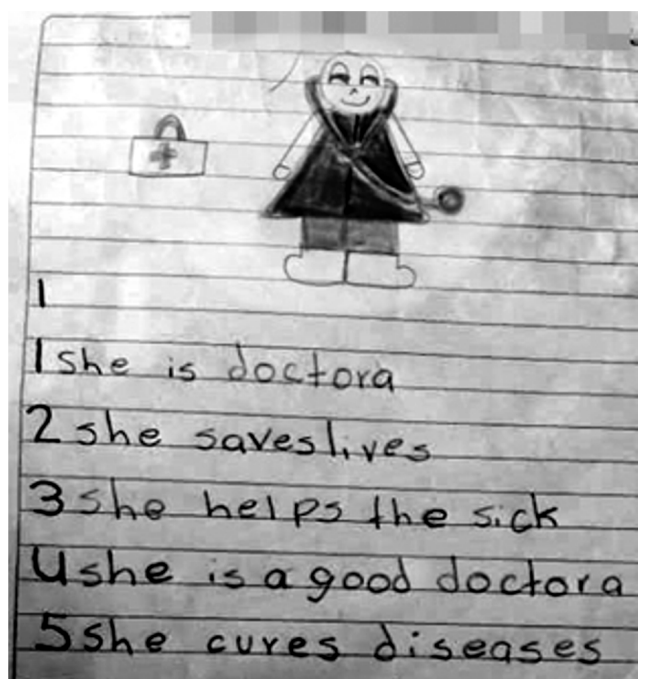

Figure 2. A Learner Creates a Female Doctor

Note. "1 she is doctora / 2 She saves lives / 3 she helps the sick / 4 she is a good doctora / 5 she cures diseases" (Class artifact 19/05/2020).

In other cases, these transformations took place in order to present more complex reflections using Spanish or English. One learner created a short comic story in which she compared Superman with a doctor, and presented doctors as superheroes explicitly with words (see Figure 3 below).

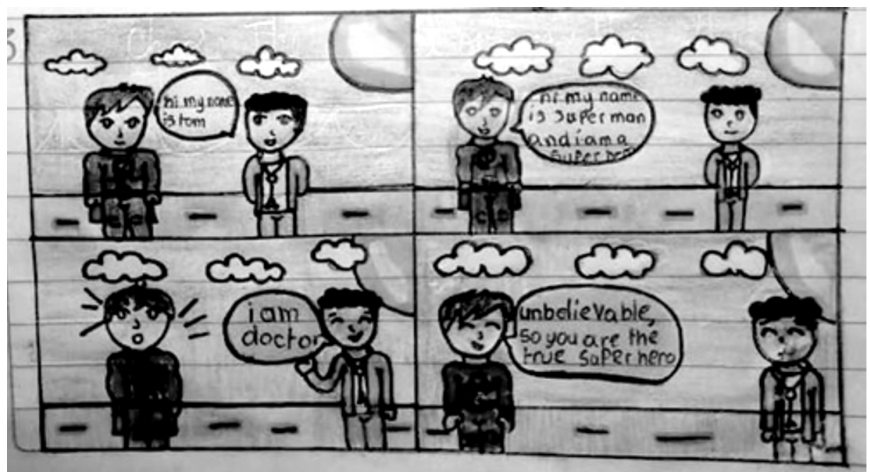

Figure 3. A Learners' Complex Reflection Using Visual Modality

Note. "hi my name is tom / hi my name is superman and $\mathrm{i}$ am a superhero / $\mathrm{i}$ am doctor / unbelievable so you are the true superhero" (Class artifact 19/05/2020). 
The way the learners transformed their designs in order to convey new meanings shows how they were reflecting on their realities. This created a space of dialogue that involved different voices such as mine as their teacher, media's, and the learners' themselves. In several cases, this dialogue implied a critical reflection on the learners' realities in the sense that they were able to express facts about their lives, challenge the messages of mainstream media, and create new meanings. Even if this kind of dialogue did not always take place, these examples show how the creation of spaces for the learners to play with linguistic and visual designs creatively allowed them to express their reflections.

\section{Swimming Upstream: Keeping Relationships among Learners Untouched at School}

One of the aims of this project was to promote dialogue and cooperation among the learners, and transform their violent and competitive relationships. The classroom management strategies sought to foster group work, listening, and participation during the lessons. However, during the implementation of a distance learning modality, I was unable to observe these interactions during an important part of the intervention. Furthermore, during the time of quarantine, the interactions among the learners were considerably reduced. In one of the final interviews with them, I asked one about his contact with their partners: "Well, with my partners I don't [have any contact], just with one, that I have on my father's Whatsapp"1 (Interview with Juan 11/05/2020). Nonetheless, during the weeks I conducted the actions at school, the interactions I had observed did not change significantly. Even if the classroom management strategies helped with listening during certain activities, and lessened violent interactions, they continued to be recurrent during the time I carried out the action plan. This contrasts with the experience of Contreras and Chapetón (2016), where they were able to foster students' interaction and cooperative learning from a critical dialogical perspective by challenging traditional teaching practices.

In this sense, although spaces for dialogue, reflection, and transformations of meaning were created, dialogic action was not reflected in a change of the learners' attitudes and their relationships in the classroom. Apart from their own limitations of this intervention, this could be due to the fact that antidialogical action exercises a pervasive force that explicitly and 100 implicitly preserves the relations of oppression in society (Freire, 2018). Different authors in critical pedagogy (Apple, 2004; Giroux, 2001) have pointed to the way schools play a role in the production and reproduction of social relations of power in society through the norms and values that are implicitly taught and that legitimate the hierarchical power relations in society (Apple, 2004). In that sense, the school practices that I observed, such as individual assessment, the segmentation of knowledge, and the promotion of competition among learners, exercise a constant force that could prevent dialogic action from taking place. Nevertheless, following Giroux (2001), this force is not deterministic and could be 
resisted if we, as teachers, construct an emancipatory curriculum that creates spaces for dialogue in which all the participants' voices can be heard.

\section{Conclusions}

This action research project aimed at promoting dialogic action through the expansion of language learners' communicative repertoires. After the process of data collection and analysis, I can say that the expansion of communicative repertoires in the English language class favored the creation of spaces for dialogue, reflection, and transformation of meanings around the participating learners' realities. Nevertheless, there is not sufficient evidence of the emergence of dialogic action, since the characteristics of antidialogical action of violent interactions and competitiveness did not significantly change during the intervention.

The findings of this study present multiple implications and challenges for language education in Colombia, where the heterogeneity of learners' communicative repertoires could be explained by both a great cultural diversity and wide social and economic disparities. Findings point to the need to embrace learners' communicative practices and repertoires in language education. This implies opening spaces for the modalities of communication that learners use, and to bring all those voices to a broader conversation in the class.

This study also challenges two assumptions that have prevented language educators and curriculum designers from implementing critical literacies in language education. Firstly, the segmentation of linguistic codes has promoted the idea that the mother tongue should be banned from the English class (Phillipson, 1992; Ortega, 2019), and that the limited linguistic resources students have could prevent reflection about complex social and moral issues in the English class (Lau, 2012). Secondly, the segmentation of language from other forms of communication has compartmentalized modes of representation in different subjects in the school curriculum (Cope \& Kalantzis, 2009).

The impact of this action research project was limited by different factors. The time constraints of the class and the need to cover the grammatical contents in the official syllabus provided limited space for conducting just a few of the planned activities. The school resources and my lack of knowledge did not allow me to work with music, audiovisual, kinesthetic, or other representational forms. Additionally, implementing the distance learning modality after the Covid-19 outbreak was challenging since providing explanations and feedback to the learners was not always possible due to their limited access to internet connection.

Finally, this study also opened the landscape for new teaching and research initiatives. New lines of inquiry should consider including other modalities of representation, the work on cross-curricular projects, and more sustained interventions and studies that could have a greater impact on the actions and transformation of learners' realities. 


\section{References}

Álvarez, J. (2016). Meaning making and communication in the multimodal age: Ideas for language teachers. Colombian Applied Linguistics Journal, 18(1), 98-115. https://doi.org/10.14483/calj. v18n1.8403

Apple, M. W. (2004). Ideology and curriculum (4 ${ }^{\text {th }}$ ed.). Routledge.

Buitrago, A. C. (2016). Improving 10th graders' English communicative competence through the implementation of the task-based learning approach. Profile: Issues in Teachers' Professional Development, 18(2), 95-110. http://dx.doi.org/10.15446/profile.v18n2.48272

Burns, A. (2009). Doing action research in English language teaching: A guide for practitioners. Routledge.

Canagarajah, S. (2017). Translingual practice as spatial repertoires: Expanding the paradigm beyond structuralist orientations. Applied Linguistics, 39(1), 31-54. https://doi:10.1093/applin/ amx041

Castro-Garcés, A. Y. (2021). Awakening sociocultural realities in pre-service teachers through a pedagogy of multiliteracies. GIST: Education and Learning Research Journal, 22, 173-197.

Contreras, J. J., \& Chapetón, C. M. (2016). Cooperative learning with a focus on the social: a pedagogical proposal for the EFL classroom. HOW, 23(2), 125-147.

Contreras, J., \& Chapetón, C. (2017). Transforming EFL classroom practices and promoting students' empowerment: Collaborative learning from a dialogical approach. Profile: Issues in Teachers' Professional Development, 19(2), 135-149. http://dx.doi.org/10.15446/profile. v19n2.57811

Cope, B., \& Kalantzis, M. (2009). "Multiliteracies": New literacies, new learning. Pedagogies: An international journal, 4(3), 164-195. http:/ / dx.doi.org/10.1080/15544800903076044

Council of Europe. (2001). A common European framework of reference for languages: Learning, teaching and assessment. Council of Europe, Language Policy Division.

Creswell, J. W. (2012). Educational research: Planning, conducting, and evaluating quantitative and qualitative research. Pearson.

Curtain, C. (2020). QualCoder 1.9 [Computer Software]. Retrieved from https://github.com/ccbogel/QualCoder/releases/tag/1.9

Dovchin, S., Pennycook, A., \& Sultana, S. (2018). Popular culture, voice and linguistic diversity: Young adults on-and offline. Palgrave MacMillan. https://doi.org/10.1007/978-3-319-61955-2

Echeverri, P. A., \& Pérez, S. (2014). Making sense of critical pedagogy in L2 education through a collaborative study group. Profile: Issues in Teachers Professional Development, 16(2), 171-184.

Freire, P. (2018). Pedagogy of the oppressed. Bloomsbury Publishing. (Original work published 1968)

Giroux, H. A. (2001). Theory and resistance in education: Towards a pedagogy for the opposition. Greenwood Publishing Group. 
Herazo, J. D. (2010). Authentic oral interaction in the EFL class: What it means, what it does not. Profile: Issues in Teachers' Professional Development, 12(1), 47-61.

Janks, H. (2010). Literacy and power. Routledge.

Kramsch, C. (2008). Ecological perspectives on foreign language education. Language teaching, 41(3), 389-408. https://doi.org/10.1017/S0261444808005065

Kress, G. R. (2003). Literacy in the new media age. Routledge.

Kubota, R. (2014). The multi/plural turn, postcolonial theory, and neoliberal multiculturalism: Complicities and implications for applied linguistics. Applied Linguistics, 37(4), 474-494. https://doi.org/10.1093/applin/amu045

Kumaravadivelu, B. (2016). The decolonial option in English teaching: Can the subaltern act? TESOL quarterly, 50(1), 66-85. https://doi.org/10.1002/tesq.202

Kumaravadivelu, B. (2006). TESOL methods: Changing tracks, challenging trends. TESOL Quarterly, 40(1), 59-81. https://doi.org/10.2307/40264511

Lau, S. M. (2012). Reconceptualizing critical literacy teaching in ESL classrooms. The Reading Teacher, 65(5), 325-329. https://doi.org/10.1002/TRTR.01050

Losada, J. J., \& Suaza, D. A. (2018). Video-mediated listening and multiliteracies. Colombian Applied Linguistics Journal, 20(1), 11-24.

Miles, M. B., \& Huberman, A. M. (1994). Qualitative data analysis: An expanded sourcebook. Sage.

Mills, G. E. (2011). Action research: A guide for the teacher researcher (with MyEducationLab). Pearson.

Ministerio de Educación Nacional (MEN) (2006). Formar en lenguas extranjeras: ¡El reto!: Lo que necesitamos sabery saber hacer. Imprenta Nacional

Ortega, Y. (2018). Using collaborative action research to address bullying and violence in a Colombian high school EFL classroom. Íkala, 25(1), 35-54. https://doi.org/10.17533/udea. ikala.v25n01a04

Ortega, Y. (2019). “Teacher, ¿Puedo Hablar en Español?” A Reflection on Plurilingualism and Translanguaging Practices in EFL. Profile: Issues in Teachers' Professional Development, $21(2), 155-$ 170. https://doi.org/10.15446/profile.v21n2.74091

Pennycook, A. (2017). Translanguaging and semiotic assemblages. International Journal of Multilingualism, 14(3), 269-282. https://doi.org/10.1080/14790718.2017.1315810

Peña, M., \& Onatra, A. (2009). Promoting oral production through the task-based learning approach: A study in a public secondary school in Colombia. Profile: Issues in Teachers' Professional Development, 11(2), 11-26.

Phillipson, P. (1992). Linguistic Imperialism. Oxford University Press.

Quintana, A. (2020). Conectividad, hipermedialidad y multimodalidad: De la cultura digital al espacio escolar. Colombian Applied Linguistics Journal, 22(2), 207-220.

Ramírez, S., \& Artunduaga, M. (2018). Authentic tasks to foster oral production among English as a foreign language learners. HOW, 25(1), 51-68. https://doi.org/10.19183/how.25.1.362 
John Steven Gómez-Giraldo

Rincón, J., \& Clavijo, A. (2016). Fostering EFL learners' literacies through local inquiry in a multimodal experience. Colombian Applied Linguistics Journal, 18(2), 67-82. http://dx.doi. org/10.14483/calj.v18n2.10610

Urrutia, W., \& Vega, C. (2010). Encouraging teenagers to improve speaking skills through games in a Colombian public school. Profile: Issues in Teachers Professional Development, 12(1), 11-31.

Vaca, A., \& Gómez, L. (2017). Increasing EFL learners' oral production at a public school through project-based learning. Profile: Issues in Teachers Professional Development, 19(2), 57-71. http:// dx.doi.org/10.15446/profile.v19n2.59889 